\title{
Impact of the Selection Criteria of Artificially Inseminated Cows on the Probability of Conception and the Occurrence of Embryonic Mortality in Senegal: Modeling Approach
}

\author{
Mohamed Moctar Mouliom Mouiche ${ }^{1,2,3}$, Adama Sow ${ }^{2}$, Miguiri Kalandi ${ }^{2}$, Serge Eugene Mpouam ${ }^{1}$, Georges \\ Anicet Ouedraogo ${ }^{3} \&$ Germain Jerome Sawadogo 2 \\ ${ }^{1}$ Ecole des Sciences et de Médecine Vétérinaire, Université de Ngaoundéré, Cameroun \\ 2 Ecole Inter-Etats des Sciences et Médecine Vétérinaires (EISMV), Laboratoire d'endocrinologie et de \\ radioimmunologie, Senegal \\ 3 Université Polytechnique de Bobo-Dioulasso. Laboratoire d'Enseignement et de Recherche en Santé et \\ Biotechnologie Animales, Burkina Faso
}

Correspondence: Mohamed Moctar Mouliom Mouiche, Ecole des Sciences et de Médecine Vétérinaire, Université de Ngaoundéré. BP: 454 Ngaoundéré, Cameroun. Tel: 237-9701-2091. E-mail: mouichemoctar@yahoo.fr

Received: December 12, 2012 Accepted: August 10, 2013 Online Published: August 15, 2013

doi:10.5539/sar.v2n4p39

URL: http://dx.doi.org/10.5539/sar.v2n4p39

\begin{abstract}
The objective of this study was to measure the relative influence of the animal's age, body condition score (BCS), glycemia at day of insemination $\left(\mathrm{D}_{0}\right)$ and the livestock management system on the probability of conception and occurrence of embryonic mortalities. In this study, 81 inseminated cows both of the Gobra Zebu breed and crossbred were sampled. Blood samples were collected the day of insemination $\left(\mathrm{D}_{0}\right)$ and twenty-one $\left(\mathrm{D}_{21}\right)$ and thirty-five $\left(\mathrm{D}_{35}\right)$ days after AI. The BCS, the age and the livestock management system were recorded for all animals before the artificial insemination (AI). The glycemia was measured on $\mathrm{D}_{0}$. Pregnancy diagnosis was performed by progesterone and pregnancy associated glycoprotein assays and transrectal palpation. A multinomial logistic model was used to analyze the effect of the selection criteria for cows on the success rate of AI.

The pregnancy diagnosis makes possible to detect $47 \%$ of pregnant cows and $26 \%$ of late embryonic mortality (LEM) at $\mathrm{D}_{60}$ post $\mathrm{AI}$. The maximum likelihood test carried out on the model permits to reject the null hypothesis $(p<0.0001)$ according to which all animals have the same chance of being pregnant $(47 \%)$. The variables thus provide a significant amount of information to explain the variability in the success rate of AI. The most significant factor was age $(p<0.0001)$, followed by the BCS, then glycemia and finally the livestock management system $(p=0.047)$. The BCS is the factor that most explains the variability in pregnant cows. For the group of LEM, age of the animal accounts for variability.
\end{abstract}

Keywords: artificial insemination, probability of conception, embryonic mortality, modeling, Senegal

\section{Introduction}

ProfiTable production in cattle breeding depends on the control of reproduction. A key question for the inseminator is to choose a cow in optimal conditions for insemination (Friggens \& Labouriau, 2007; Demetrio et al., 2007). The choice of a cow to be inseminated depends not only on factors such as age, milk production level and feeding system but also on the basic biology of reproduction. The probability of a cow to calf at a given time is an important factor to take into account to decide on when to inseminate (Moreira et al., 2000; Friggens \& Labouriau, 2007).

A number of factors such as the negative energy balance, poor body condition, and reproductive disorders associated to calving are known to induce an increase of the postpartum anoestrus (Moreira et al., 2000; Ponter et al., 2005). All these factors affect the rate of success after AI and the occurrence of embryonic mortalities. However, it is unclear whether the effect on the conception rate is a direct effect or a consequence of the interaction between several factors (Chebel et al., 2004; Romano et al., 2007; Demetrio et al., 2007). Concerning 
follicular development for example, previous studies indicate that factors such as negative energy balance may directly affect the viability of resulting oocytes (Butler, 2003).

It is interesting to study these factors in sub-Saharan Africa, considering their importance reported in the literature reviews but also mainly because of their accessibility on the field. Age and body condition score (BCS) are parameters that can easily be estimated in various livestock management systems. Thus, the objective of this study was to measure the relative influence of animal's age, its BCS, blood glucose level at Day $0\left(\mathrm{D}_{0}\right)$, the day of the AI, and the breeding system on the probability of conception and the occurrence of embryonic mortalities.

\section{Material and Methods}

\subsection{Study Area}

The study was conducted in the rural and urban regions of Dakar and Thiès (Figure1), located in the Sahelian zone between 400 and $600 \mathrm{~mm}$ isohyets. The climate is the Sahelian type characterized by a rainy season of variable duration (July to October) and a dry season (November-June). The lowest temperatures $\left(15-20^{\circ} \mathrm{C}\right)$ are recorded between January and March. And in the rest of the year, temperature oscillates between $20^{\circ}$ and $40^{\circ} \mathrm{C}$. The natural pasture is abundant in the rainy season and consists of grasses and legumes. During the rainy season, small traditional farmers graze their cattle on the natural pasture. The traditional or extensive livestock management system more prevalent, and is characterized by transhumance with the primary goal being the search of pasture and water points.

The local breeds reared in these regions are the Gobra and Maure zebus (Bos indicus), the N'Dama (Bos taurus africanus), and the Djakore breed (Gobra*N'Dama). The cattle population was at 21,270 and 183,541 heads in Dakar and in Thies, respectively (Direl, 2010). Artificial insemination was introduced in these areas in the middle of 1990's, and the most used semen belonged to Montbeliarde, Holstein, Jersey and Guzerat breeds (Kouamo et al., 2009).

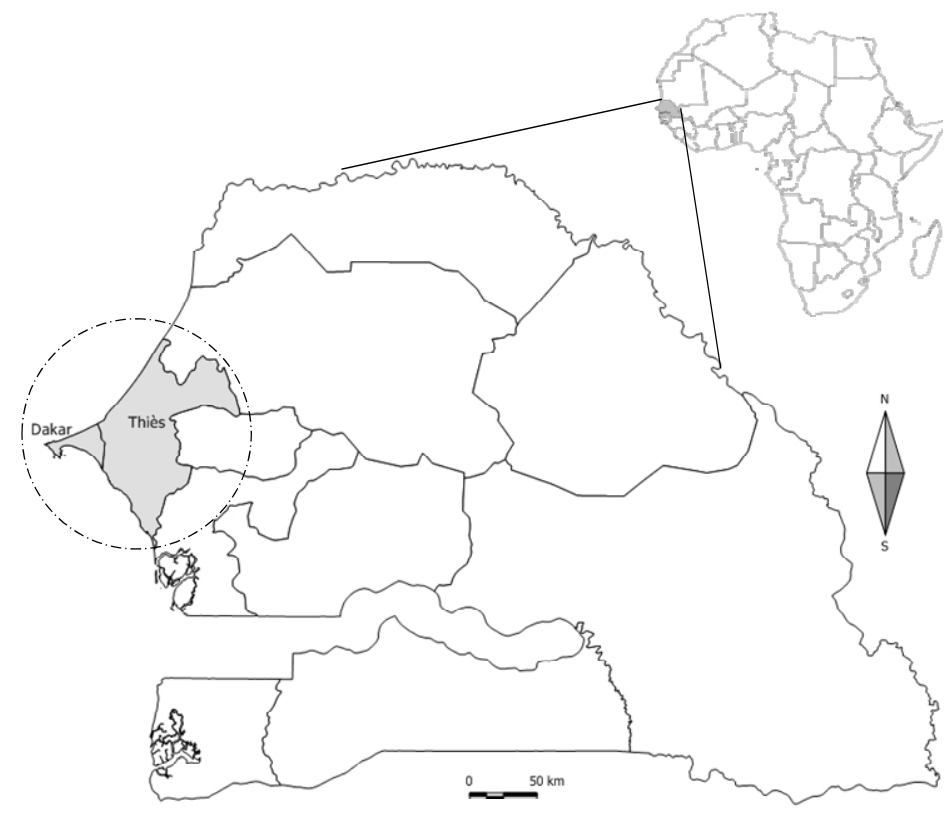

Figure 1. Map of Senegal showing the study zone

\subsection{Animal and Blood Sampling}

The study was conducted on 81 cows from 25 herds, inseminated within the framework of the National Artificial Insemination Programme. Forty four cows (54.3\%) were Gobra zebus reared in an extensive management system from the region of Thiès and the remaining 37 cows were both Gobra and crossbred cattle (45.7\%) selected in a semi-intensive system from the region of Dakar. These were heifers or cows with more than 3 months postpartum period, the body condition score (BCS) was between 2.5 and 4 and the average age was $6 \pm 2$ years. The body condition score was evaluated on a grid of 0-5 applied to West African zebus (Vall \& Bayala, 2004). The selected animals were identified using ear tags and all the information concerning them were recorded in a data base. These females were reared in extensive or semi-extensive systems, characterized by the search of natural pasture during the day. The animals returned to the paddock at sunset where they were supplemented with animal feed before milking. The animals drank from puddles during the pasture. 
The conditions required from farmers by the national insemination program were to practice stabling for the selected cows, the ability to ensure feed supplementation and to provide healthcare. The inseminations were performed after inducing heat using a protocol associating the vaginal spiral $\left(\mathrm{PRID}^{\mathrm{ND}}\right)$, prostaglandin $\mathrm{PGF}_{2 \alpha}$ and Pregnant Mare Serum Gonadotropin (PMSG).

Blood samples were collected in vacuum glass heparinated tubes by puncturing into the jugular vein at day of insemination $\left(\mathrm{D}_{0}\right)$ and twenty-one $\left(\mathrm{D}_{21}\right)$ and thirty-five $\left(\mathrm{D}_{35}\right)$ days after $\mathrm{AI}$, and after $\mathrm{AI}$, then centrifuged $(3000$ $\mathrm{rpm}$ for 20 minutes) in order to obtain the plasma which was stored at $-20^{\circ} \mathrm{C}$ till the biochemical analyses were performed.

\subsection{Pregnancy Diagnosis}

The plasma concentrations of PAG and progesterone were measured using the radioimmunological assay systems (RIA) (Zoli et al., 1992; Sousa et al., 2003), in order to determine the physiological status (pregnant, non pregnant, or embryonic mortality) of the inseminated cows. The suspected pregnant cows had blood progesterone levels higher than $2 \mathrm{ng} / \mathrm{ml}$ after 21 days post AI (Thimonier, 2000). The positivity threshold for the PAG was $0.8 \mathrm{ng} / \mathrm{ml}$ in cows on the 35th day after AI (Sousa et al., 2003).

Transrectal palpation was carried out two months after AI in order to confirm the pregnancy status in the cows. The signs of confirmation were: asymmetrical horns with thinness of the wall of the pregnant uterine horn, the presence of a fluctuating fluid and an amniotic membrane. The association between different assays (PAG and progesterone) and the diagnosis by transrectal palpation led to the detection of various physiological status 60 days after AI (Table 1): non pregnant or Early Embryonic Mortality, Late Embryonic Mortality and pregnant.

Table 1. Correspondence between different situations after AI and the results of progesterone and PAG assays

\begin{tabular}{lllll}
\hline Progesterone at $\mathrm{D}_{0}$ & Progesterone at $\mathrm{D}_{21}$ & PAG at $\mathrm{D}_{35}$ & Transrectal palpation at $\mathrm{D}_{60}$ & Diagnosis \\
\hline Low & low & undetected & undetected & EAM or NP \\
Low & high & undetected & undetected & LAM \\
Low & high & detected & undetected & LAM \\
Low & high & detected & detected & Pregnant \\
\hline
\end{tabular}

\subsection{Glycemia on the Day of Insemination}

The blood glucose level was assessed in animals on the day of insemination $\left(\mathrm{D}_{0}\right)$ by colorimetric assay. The principle of the assay is the glucose oxidase method (Trinder, 1969). The analyses were carried out using commercial kits (BIOSYSTEMS ${ }^{\circledR}$ S.A., Barcelona, Spain). The experimental protocols were provided by the manufacturers. The colometric reactions were measured using spectrophotometer (BIOSYSTEMS ${ }^{\circledR}$ BTS-310).

\subsection{Statistical Analysis}

Data were computed on Excel $^{\circledR}$ and were analyzed using XLSTAT ${ }^{\circledR}$ software for the different calculations and graphic representations. The results were expressed as mean \pm SD. One-way ANOVA test followed by multiple comparison tests were used to compare the different means of BCS, age and glycemia according to the physiological status. Tukey's test was used for multiple comparison tests (pariwise comparisons). Khi squared test of independence was used to compare the proportions of the different physiological states depending on the breeding system. Differences were considered to be statistically significant if $p<0.05$.

A multinomial logistic model was used to analyze the effect of selection criteria for inseminated cows on the probability of conception and the occurrence of embryonic mortality (Hosmer \& Lemeshow, 2000). This model is a generalization of the classical logistic model when the response variable has more than two categories, in our case the dependent variable is the diagnosis of gestation (DG), with three categories: pregnant, non pregnant or late embryonic mortality (LEM). All results are given relatively to a reference category; the fixed category in this study was the non pregnant group. Other categories are expressed with respect to this reference using a linear combination of explanatory variables (Heinze \& Schemper, 2002). The explanatory variables used were: BCS, age, livestock management system and the glycemia on $\mathrm{D}_{0}$.

$$
\text { LOGIT }_{\text {Pregnant }}=\left[\log \left(\frac{P(D G=\text { Pregnant })}{P(D G=\text { Non Pregnant })}\right)\right]=a_{0}+a_{1} B C S+a_{2} \text { Age }+a_{3} \text { Glycemia }+a_{4} \text { Breeding Syst } .
$$




$$
\operatorname{LOGIT}_{\mathrm{LEM}}=\left[\log \left(\frac{P(D G=\text { LEM })}{P(D G=\text { Non Pregnant })}\right)\right]=a_{0}+a_{1} B C S+\dot{a}_{2} \text { Age }+\dot{a}_{3} \text { Glycemia }+\dot{a}_{4} \text { Breeding Syst. }
$$

$\mathrm{a}_{0}, \mathrm{a}_{1}, \mathrm{a}_{2} \ldots$ are the model parameters estimated. The different probabilities can be calculated in the following way

$$
\begin{aligned}
& \text { Probability of Pregnancy }=\left(\frac{e^{\text {LOGIT Pregnant }}}{1+\left[e^{\text {LOGIT Pregnant }}+e^{\text {LOGIT LEM }]}\right.}\right) \\
& \text { Probability of Embryonic loss }=\left(\frac{e^{\text {LOGIT LEM }}}{1+\left[e^{\text {LOGIT Pregnant }}+e^{\text {LOGIT LEM }]}\right.}\right) \\
& \text { Probability of Non Pregnancy }=1-\text { Probability of Pregancy }- \text { Probability of Embryonic loss }
\end{aligned}
$$

In our study the probability of pregnancy is defined as the percentage of chance that an animal is found pregnant two months after AI. The probability of the occurrence of embryonic losses refers to the percentage of chance that an animal does not keep the pregnancy for up to two months after AI. The built predictive model was used to evaluate the effect of the evolution of the animal's age on the probability of pregnancy and occurrence of embryonic mortalities according to the breeding system.

\section{Results}

\subsection{Univariate Approach}

The Pregnancy diagnosis by rectal palpation at $\mathrm{D}_{60}$, progesterone assays at $\mathrm{D}_{21}$ and PAG assays at $\mathrm{D}_{35}$, allowed us to group inseminated cows into pregnant, non-pregnant and LEM. Out of 81 inseminated cows, 38 (47\%) were pregnant, $21(26 \%)$ have aborted (LEM) and $22(27 \%)$ were not pregnant at $\mathrm{D}_{60}$. The highest pregnancy rate and the lowest rate of LEM were found in the Dakar region (Table 2). The BCS was significantly higher in pregnant cows $(p=0.000)$ and also had a lower age average $(p=0.001)$. The LEM group had a low glycemia compared to pregnant cows $(\mathrm{p}=0.005)$.

Table 2. Comparison of different factors with respect to the physiological status of cow

\begin{tabular}{llllll}
\hline & & $\begin{array}{l}\text { Pregnant } \\
(\mathrm{n}=38)\end{array}$ & $\begin{array}{l}\text { LAM } \\
(\mathrm{n}=21)\end{array}$ & $\begin{array}{l}\text { Non Pregnant } \\
(\mathrm{n}=22)\end{array}$ & p-value \\
\hline \multirow{3}{*}{ Means \pm SD } & BCS & $3.3 \pm 039^{\mathrm{a}}$ & $2.92 \pm 0.41^{\mathrm{b}}$ & $2.88 \pm 0.39^{\mathrm{b}}$ & 0 \\
& Glycemia $\mathrm{D}_{0}$ & $2.33 \pm 1.8^{\mathrm{a}}$ & $1,17 \pm 0,67^{\mathrm{b}}$ & $2.05 \pm 0.9^{\mathrm{ab}}$ & 0.005 \\
& Age & $4.57 \pm 1.09^{\mathrm{a}}$ & $6,66 \pm 1,61^{\mathrm{b}}$ & $6.31 \pm 1.3^{\mathrm{b}}$ & 0.001 \\
\multirow{2}{*}{ Livestock Systems (\%) } & Extensive $(\mathrm{n}=44)$ & $30.72^{\mathrm{a}}$ & $34.36^{\mathrm{a}}$ & $36.9^{\mathrm{a}}$ & 0 \\
& Semi-Intensive $(\mathrm{n}=37)$ & $70.67^{\mathrm{b}}$ & $13.51^{\mathrm{b}}$ & $15.8^{\mathrm{b}}$ & \\
\hline
\end{tabular}

${ }^{a . b}$ Means with different superscript letter are significantly different horizontally $(p<0.05)^{a . b}$ Proportions with different superscript letter are significantly different vertically $(p<0.05)$ SD: Standard Deviations

\subsection{Modeling Approach}

The result of the likelihood test shows that all animals have not equal chance of being pregnant $(\mathrm{P}<0.0001)$. The variables (BCS, age, glycemia, and breeding system) thus provide a significant amount of information to explain the variability of the success rate of insemination. The coefficient of determination $\left(\mathrm{R}^{2}\right)$ of the model is 0.55 . All factors have a significant effect (Table 3 ) on the success rate of insemination. The most significant factor was age $(\mathrm{p}<0.0001)$, followed by the BCS $(\mathrm{p}=0.001)$, then the glycemia $(\mathrm{p}=0.003)$ and finally the breeding system $(\mathrm{p}$ $=0.047)$.

The Wald test was used to verify the significance of each coefficient in each regression. The factors that most explained the variability in the conception rate of the pregnant cows were age $(p=0.002)$, BCS $(p=0.014)$, and the breeding system $(\mathrm{p}=0.023$.) The variable that explains the probability of occurrence of embryonic mortality was glycemia $(\mathrm{p}=0.005)$ at $\mathrm{D}_{0}($ Table 4$)$.

The built predictive model was used to evaluate the effect of the evolution of animal's age on the probability of 
conception and occurrence of embryonic mortalities according to the breeding system. We found that increasing the animal's age has an impact on its fertility (Figure 2). It is translated by a decrease in the probability of conceiving and an increase in that of embryonic mortalities whatever the breeding system. The probability of conceiving and the occurrence of LEM varied according to the breeding system but when the cows had more than 9 years old the various probabilities were similar (Figure 2).

Table 3. Significance of model variables

\begin{tabular}{llllll}
\hline Source & $\mathrm{DF}$ & $\mathrm{Khi}^{2}$ (Wald) & $\mathrm{Pr}>$ Wald & $\mathrm{Khi}^{2}(\mathrm{LR})$ & $\mathrm{Pr}>\mathrm{LR}$ \\
\hline BCS & 2 & 9.857 & 0.007 & 13.934 & 0.001 \\
Glycemia $\mathrm{D}_{0}$ & 2 & 8.052 & 0.018 & 11.325 & 0.003 \\
Age & 2 & 13.063 & 0.001 & 18.949 & $<0.0001$ \\
Livestock Systems & 2 & 5.409 & 0.067 & 6.132 & 0.047 \\
\hline
\end{tabular}

Test of the null hypothesis $\mathrm{H} 0: \mathrm{Y}=0.47, \mathrm{R}^{2}=0.55$.

Table 4. Significance of model

\begin{tabular}{lllllll}
\hline Category & Source & Value $^{\#}$ & Standard- error & ${\text { Wald } \mathrm{Khi}^{2}}^{2}$ & $\mathrm{Pr}>\mathrm{Khi}^{2}$ & Odds ratio \\
\hline \multirow{6}{*}{ Pregnant } & Intercept & -2.906 & 3.631 & 0.64 & 0.424 & \\
& BCS & 2.772 & 1.123 & 6.096 & 0.014 & 15.998 \\
& Glycemia $\mathrm{D}_{0}$ & -0.25 & 0.304 & 0.675 & 0.411 & 0.779 \\
& Age & -1.016 & 0.325 & 9.754 & 0.002 & 0.362 \\
& Extensive & 0 & 0 & & & \\
& Semi-Intensive & 1.993 & 0.879 & 5.141 & 0.023 & 7.336 \\
& Intercept & 2.781 & 3.201 & 0.755 & 0.385 & \\
& BCS & -0.973 & 0.986 & 0.973 & 0.324 & 0.378 \\
& GAM & -1.225 & 0.432 & 8.042 & 0.005 & 0.294 \\
& Age & 0.224 & 0.245 & 0.837 & 0.36 & 1.251 \\
& Extensive & 0 & 0 & & & \\
& Semi-Intensive & 1.629 & 0.959 & 2.885 & 0.089 & 5.097 \\
\hline
\end{tabular}

${ }^{\#}$ model parameters $\left(\mathrm{a}_{0}, \mathrm{a}_{1}, \mathrm{a}_{2} \ldots\right)$.

\section{Discussion}

The success rate of insemination recorded in this study was $47 \%$. Our results are similar to those obtained in insemination programs in Senegal (Kouamo et al., 2009; Kouamo et al., 2010), but is however lower than the optimum of $60 \%$ targeted by the National Artificial Insemination Program in Senegal (Kouamo et al., 2009). Out of the 43 cows diagnosed non pregnant at $\mathrm{D}_{60}, 21(26 \%)$ were cases of LEM. This embryonic mortality rate is comparable to the estimated rate of LEM in dairy cows (5 and 12\%) reported by Santos et al. (2009). Silke et al. (2002) observed embryo losses between $\mathrm{D}_{28}$ and $\mathrm{D}_{84}$ of gestation representing $7.2 \%$ of loss in cows and $6.1 \%$ in heifers. Several factors could account for this high rate of LEM amongst which genetic, endocrine, immunological, infectious, nutritional and environmental factors (Chebel et al., 2004, Romano et al., 2007). Each of these factors may act alone or in association/interaction with several others, their respective effects can be then amplified and consequently initiate disorders of increasing gravity (Ducrot et al., 1996).

This work aimed at investigating the interactions between factors by a multivariate approach of the main factors influencing the success rate of AI, contrarily to the univariate approaches that are most often used in the analysis of the results of AI in sub-Saharan Africa (Kouamo et al., 2009). To identify one or several levels at which research efforts should win priority and the points on which the inseminators should be careful about when choosing cows to inseminate, it is important to evaluate the part of variability in the reproductive performance brought about by each factor (Dohoo et al., 2001). 


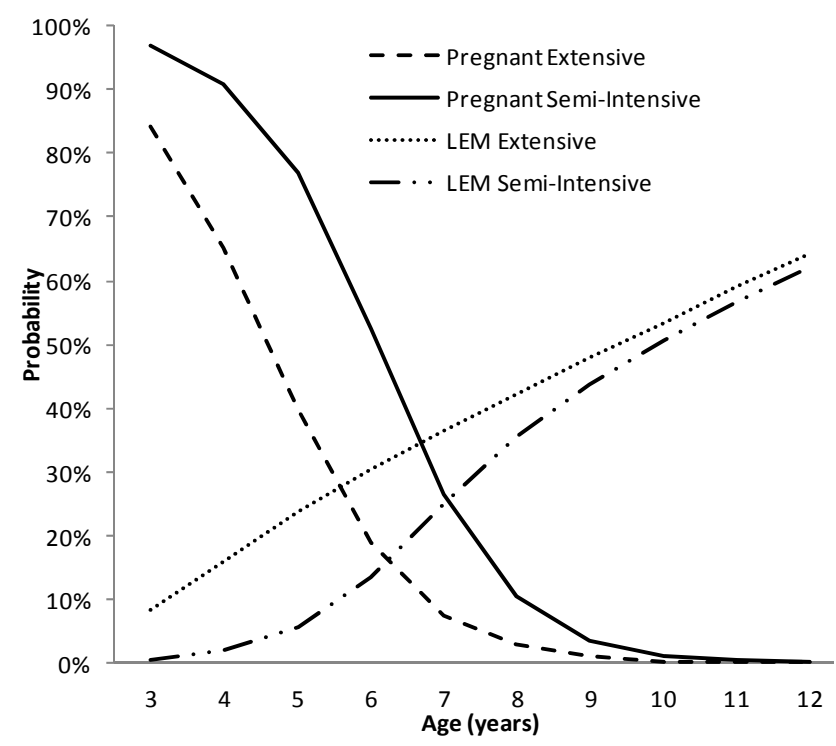

Figure 2. Relationship between the evolution of cow's age, probability of conception and occurrence of embryonic mortality estimated with the model according to the livestock systems

The built predictive model explains $55 \%\left(\mathrm{R}^{2}=0.55\right)$ of the variability in the success rate of AI (Table 3$)$. The remaining variability could be explained by effects that are neither identified nor measured in this analysis (Blanc \& Agabriel, 2006). The model seems adequate, the statistical tests performed on the model (Table 3) permits the rejection of the null hypothesis $(\mathrm{p}<0.0001)$ which stipulates that all animals have the same chance to be pregnant $(46.9 \%)$. The parameters introduced in the model thus provide a significant amount of information which explains the variability of the success rate of AI.

The contribution of variables in the model fit was significant. Otherwise, they could be removed from the model. The model thus specified would be accepTable from a statistical point of view. The coefficients for each variable and for each modality (except for the reference category) were determined in order to assess the different probabilities of conception and occurrence of LEM (Table 4). The variables that most affect conception rate were age $(p=0.002)$, BCS $(p=0.014)$, and the breeding system $(p=0.023)$. Concerning the probability of embryonic mortality, the glycemia $(\mathrm{p}=0.005)$ at $\mathrm{D}_{0}$ most affected it. On the other hand, the odds ratios allowed an easier interpretation of results (they were calculated as the exponential of the coefficient) (Heinze \& Schemper, 2002). For example the fact that an animal shifts from extensive to semi-intensive system significantly improved ( $\mathrm{p}=$ 0.023 ) the probability of conception of $7.3 \%$. It would reduce the rate of occurrence of LEM of $5.1 \%$. In order to increase the success rate of AI, these variables should be taken into account by inseminators and breeders in the selection of animals to be inseminated.

The effect of the breeding system is one of the important factors of variation in the success rate of AI. This factor would reflect the differences in livestock management which exist between breeders, in terms of herd management and feeding. This assumption goes in the direction of the results of Garcia-Ispierto (2007) for which the breeding effect was not significant in a study where all farms were homogeneous in terms of livestock management. The reproduction management practices implemented by livestock breeders may affect the performance of all animals in the herd. However, the effect of the practices does not always apply uniformly across all animals in the herd; the breeders can indeed exert an individual action, only on some cows.

The effect of animal's age on embryonic and fetal losses has rarely been described (Chebel et al., 2004). It is true that this kind of study has a significant bias, namely the low percentage of animals that have had more than one abortion among the older cows. Indeed, in most cases this reproductive disease is accompanied by a reform of the animal. The built predictive model was allowed to simulate the effect of the variation of the animals' ages according to the farming system on the probability of conception and the occurrence of embryonic mortality (Figure 2). The increase in the animal's age had an impact on the success rate of AI. The probability of conception and the occurrence of LEM vary depending on the breeding system but when cows have more than 9 years old the different probabilities would be similar (Figure 2). Thus, to a certain age, whatever the breeding systems, the age of animal is the most important factor. This forecast matches that of Thurmond \& Picanso 
(1993), according to them, embryonic mortality is more common in multiparous cows or in cows with more than 5 lactations than in cows between the second and fourth lactation. Bister (2006) also showed that the fertility gradually decreases in ruminants according to the age.

Body condition score is widely used to assess the energy balance in dairy cows. The BCS (excessive or insufficient) is a factor exerting a very significant effect on reproductive efficiency (Humblot, 2001). A number of authors highlight the relationship between BCS and embryonic mortality. (Pinto et al., 2000; Disenhaus et al., 2005; Ponter et al., 2005; Ponsart et al., 2007). The precocious use for reproduction of animals with poor body conditions or those not yet stabilized therefore increases the risk of embryonic mortality (Lopez-Gatius et al., 2002; Freret et al., 2005; Grimard et al., 2006). If other authors have done this, why do you want to report it again?

In our study, the odds ratios allowed conclude that if the BCS increases by one the probability for a inseminated cow to be pregnant is increased by $16 \%$ (Table 4). In the study of Freret et al. (2005), the drop of body condition score between 0 and 60 days postpartum had an effect on the rate of non-fertilization or early embryonic mortality (EEM). This rate of EEM is $41.7 \%$ for a loss greater than one point, against $29.8 \%$ when the loss is less than one point. The rates of LEM are lower in thin cows or in fair body condition than in fat cows at the time of insemination, with LEM rates being respectively $13.5 \%, 15.1 \%$ and $24.5 \%$ (Froment, 2007). The effects of quantitative factors are not always linear. This non-linearity most often induces a multi-layered consideration of factors. For some factors, the median values are opposed to extreme values (deficiency / excess) (Harman et al., 1996). For example a BCS of 5 in a cow would be incompatible with fertility (López-Gatius et al., 2002).

The glycaemia at Do was used to evaluate the energy balance of cows. In practice inseminators base themselves only on the BCS to assess the body condition of animals. The energy balance at the time of AI or at beginning of pregnancy may affect the embryonic development (Silke et al., 2002). A negative energy balance would result in a lower progesterone concentration and thus increase the possibility of embryonic losses (Hanzen et al., 1999). Many authors demonstrated the role of energy deficit on the occurrence of LEM. (Ayalon, 1978; Reist et al., 2003). The relationship between blood glucose and fertility is also very controversial. It would seem that blood glucose is associated with infertility when it is very far below its usual values (Miettinen, 1991).

The present work is integrated in a process of developing tools for the assessment of the reproductive capacity (Ingrand et al., 2002; Laloux et al., 2008). It would be important to focus such studies on risk factors that contribute most to the variability in order to ensure a range of far-reaching recommendations that could be made. The goal is to develop a model to predict the likelihood of success of AI on the scale of the herd taking into account individual variability (Blanc \& Agabriel, 2006). In the future, the knowledge of the probabilities of success of AI by inseminators will be an indicator that will help in the management of inseminations. According to the predicted probability, this tool will guide them on the decision on whether to inseminate or not and on the budget to be allocated to semen (Laloux et al., 2008).

\section{Conclusion}

This study showed that the selection criteria of candidate cows for AI are very important factors for the success of AI programs. The inseminators must therefore pay more attention when inseminating, for the evolution of traditional breeding depends on the supply of local markets in meat and milk.

\section{Acknowledgments}

We are very grateful to the "Agence Universitaire de la Francophonie" (AUF) and the National Artificial Insemination Program (PNIA) of Senegal for supporting these research works. We also thank the breeders, the inseminators, all the staffs of the laboratory of Biochemistry of EISMV of Dakar for their availability and finally Dr. Stanly Tebug. for critical reading of the manuscript.

\section{References}

Ayalon, N. (1978). A review of embryonic mortality in cattle. Journal of Reproduction and Fertility, 54, 483-493. http://dx.doi.org/10.1530/jrf.0.0540483

Bister, J. L. (2006). Analyse de certains paramètres pouvant influencer les résultats d'insémination artificielle chez la brebis. Filière Ovine et Caprine, 11, 45-60.

Blanc, F., \& Agabriel, J. (2006). Intérêt de la modélisation pour interpréter l'influence de la date de vêlage sur la durée de l'anoestrus post-partum chez la vache allaitante. Rencontre Recherche Ruminant, 13, 277.

Butler, W. R. (2003). Energy balance relationships with follicular development, ovulation and fertility in postpartum dairy cows. Livestock Production Science, 83, 211-218. 
http://dx.doi.org/10.1016/S0301-6226(03)00112-X

Chebel, R. C., Santos, J. E. P., Reynolds, J. P., Cerri, R. L. A., Juchem, S. O., \& Overton, M. (2004). Factors affecting conception rate after artificial Insemination and pregnancy loss in lactating dairy cows. Animal Reproduction Science, 8, 239-255. http://dx.doi.org/10.1016/j.anireprosci.2003.12.012

Demetrio, D. G. B., Santos, R. M., Demetrio, C. G. B., \& Vasconcelos, J. L. M. (2007). Factors Affecting Conception Rates Following Artificial Insemination or Embryo Transfer in Lactating Holstein Cows. Journal of Dairy Science, 90, 5073-5082. http://dx.doi.org/10.1016/j.anireprosci.2003.12.012

Direl, (Direction de l'élevage). (2010). Rapport annuel sur l'état des ressources animales et zoo sanitaires. Ministère de l'élevage du Sénégal, p. 40.

Disenhaus, C., Grimard, B., Trou, G., \& Delaby, L. (2005). De la vache au système: s'adapter aux différents objectifs de reproduction en élevage laitier? Rencontre Recherche Ruminant, 12, 125-135.

Dohoo, I. R., Tillard, E., Stryhn, H., \& Faye, B. (2001). The use of multilevel models to evaluate sources of variation in reproductive performance in dairy cattle in Reunion Island. Preventive Veterinary Medicine, 50, 127-144. http://dx.doi.org/10.1016/S0167-5877(01)00191-X

Ducrot, C., Legay, J. M., Gröhn, Y. T., Enevoldsen, C., \& Calavas, D. (1996). Approach to complexity in veterinary epidemiology: Example of cattle reproduction. Nature Science et Société, 4, 23-33.

Freret, S., Charbonnier, G., Congnard, V., Jeanguyot, N., Dubois, P., \& Friggens, N. C., Labouriau, R. (2007). Effet du numéro d'oestrus et du nombre de jours après le vêlage sur la probabilité de conception chez les vaches laitières. Rencontre Recherche Ruminant, 14, 367

Froment, P. (2007). Note d'état corporel et reproduction chez la vache laitière. These Médecine. Véterinaire: Alfort, France. p. 112.

Garcia-Ispierto, I. (2007). Factors affecting the fertility of high producing dairy herds in northeastern Spain. Theriogenology, 67, 632-638. http://dx.doi.org/10.1016/j.theriogenology.2006.09.038

Grimard, B., Freret, S., Chevallier, A., Pinto, A., Pommrt, C., \& Humblot, P. (2006). Genetic and environmental factors influencing first service conception rate and late embryonic/foetal mortality in low fertility dairy herds. Animal Reproduction Science, 91, 31-44. http://dx.doi.org/10.1016/j.anireprosci.2005.03.003

Hanzen, C. H., Lourtie, O., Drion, P. V., Depierreux, C., \& Christians, E. (1999). La mortalité embryonnaire: Aspects cliniques et facteurs étiologiques dans l'espèce bovine. Annales de Médecine. Vétérinaire, 143, 91-118. http://hdl.handle.net/2268/8978

Harman, J. L., Gröhn, Y. T., Erb, H. N., \& Casella, G. (1996). Event time analysis of the effect of 60-day milk production on the parturition-to-conception interval in dairy cows. American Journal of Veterinary Research, 57, 634-639.

Heinze, G., \& Schemper, M., (2002). A solution to the problem of separation in logistic regression. Statistics in Medicine, 21, 2409-2419. http://dx.doi.org/10.1002/sim.1047

Hosmer, D. W., \& Lemeshow, S. (2000). Applied Logistic Regression (2nd ed.), New York, NY: John Wiley and Sons. http://dx.doi.org/10.1002/0471722146

Humblot, P. (2001). Use of pregnancy specific proteins and progesterone assays to monitor pregnancy and determine the timing, frequencies and sources of embryonic mortality in ruminants. Theriogenology, 56, 1417-1433. http://dx.doi.org/10.1016/S0093-691X(01)00644-6

Ingrand, S., Dedieu, B., Agabriel, J., \& Perochon, L. (2002). Modélisation du fonctionnement d'un troupeau bovin allaitant selon la combinaison des règles de conduite. Premiers résultats de la construction du simulateur Simball. Rencontre Recherche Ruminant, 9, 61-64.

Kouamo, J., Habimana, S., Alambedji, B. R., Sawadogo, G. J., \& Ouedraogo, G. A. (2010). Séroprévalence de la brucellose, de l'IBR et de la BVD et impact sur la reproduction des femelles zébus Gobra et croisements inséminées en milieu traditionnel dans la région de Thiès au Sénégal. Revue de Médecine Vétérinaire, 161, 314-321.

Kouamo, J., Sow, A., Leye, A., Sawadogo, G. J., \& Ouédraogo, G. A. (2009). Amélioration des performances de production et de reproduction des bovins par l'utilisation de l'insémination artificielle en Afrique Sub-saharienne et au Sénégal en particulier: état des lieux et perspectives, Revue Africaine de Santé et de Productions Animales, 7, 139-148. 
Laloux, L., Bastin, C., Glorieux, G., Bertozzi, C., \& Gengler, N. (2008). Développement d'un outil de prédiction de la probabilité de réussite à l'insémination chez la vache laitière à partir des données du contrôle laitier. Rencontre Recherche Ruminant, 15, 373.

Lopez-Gatius, F., Santolaria, P., Yaniz, J., Rutland, J., \& Lopez-Bejar, M. (2002). Factors affecting pregnancy loss from gestation day 38 to 90 in lactating dairy cows from a single herd. Theriogenology, 57, 1251-1261. http://dx.doi.org/10.1016/S0093-691X(01)00715-4

Moreira, F., Risco, C., Pires, M. F. A., Ambrose, J. D., Drost, M., Delorenzo, M., \& Thatcher, W.W. (2000). Effect of body condition on reproductive efficiency on lactating dairy cows receiving a timed insemination. Theriogenology, 53, 1305-1319. http://dx.doi.org/10.1016/S0093-691X(00)00274-0

Pinto, A., Bouca, P., Chevallier, A., Freret, S., Grimard, B., \& Humblot, P. (2000). Source de variation de la fertilité et des fréquences de mortalité embryonnaire chez la vache laitière. Rencontre Recherche Ruminant, 7, 213-215.

Ponsart, C., Dubois, P., Charbonnier, G., Leger, T., Freret, S., \& Humblot, P. (2007). Evolution de l'état corporel entre 0 et 120 jours de lactation et reproduction des vaches laitières hautes productrices. In Journées nationales des GTV. Nantes, France. pp. 347-356.

Ponter, A., Guelou, K., \& Duvaux-Ponter, C. (2005). Influence de l'alimentation sur la mortalité embryonnaire. Point Vet., 36,100-105.

Reist, M., Erdin, D. K., Von Euw, D., Tschumperlin, K. M., Leuenberger, H., Hammon, H. M., ... Blum, J. W. (2003). Postpartum reproductive function: association with energy, metabolic and endocrine status in high yielding dairy cows. Theriogenology, 59, 1707-1723. http://dx.doi.org/10.1016/S0093-691X(02)01238-4

Romano, J. E, Thompson J. A., Kraemer D. C., Westhusin M. E., Forrest D. W., \& Tomaszweski, M. A. (2007). Early pregnancy diagnosis by palpation per rectum: Influence on embryo/fetal viability in dairy cattle. Theriogenology, 67, 486-493. http://dx.doi.org/10.1016/j.theriogenology.2006.08.011

Santos, J. E. P., Rutigliano, H. M., \& SaFilho, M. F. (2009). Risk factors for resumption of postpartum estrous cycles and embryonic survival in lactating dairy cows. Animal Reproduction Science, 110, 207-221. http://dx.doi.org/10.1016/j.anireprosci.2008.01.014

Silke, V., Diskin, M. G., Kenny, D. A., Boland, M. P., Dillon, P., Mee, J. F., \& Sreenan, J. M., (2002). Extent, pattern and factors associated with late embryonic loss in dairy cows. Animal Reproduction Science, 71, 1-12. http://dx.doi.org/10.1016/S0378-4320(02)00016-7

Sousa, N. M., Zongo, M., Pitala, W., Boly, H., Sawadogo, L., Sanon, M., ... Beckers, J. F. (2003). Pregnancy-associated glycoprotein concentrations during pregnancy and the postpartum period in Azawak zebu cattle. Theriogenology, 59, 1131-1142. http://dx.doi.org/10.1016/S0093-691X(02)01160-3

Thimonier, J. (2000). Determination de l'etat physiologique des femelles par analyse des niveaux de progesterone. INRA Production Animale, 13, 177-183.

Thurmond, M. C., \& Picanso, J. P. (1993). Fetal loss associated with palpation per rectum to diagnose pregnancy in cows. Journal of the American Veterinary Medical Association, 203, 432-435.

Trinder, P. (1969). Determination of glucose in blood using glucose oxidase with an alternative oxygen acceptor. Annals of Clinical Biochemistry, 6, 24-27. http://dx.doi.org/10.1136/jcp.22.2.158

Vall, E., \& Bayala, I. (2004). Note d'état corporel des zébus soudanais. In Production animale en Afrique de l'Ouest fiche technique, 12, 1-8.

Zoli A, P., Guilbault, L. A., Delahaut, P., Benitez O. W., \& Beckers J. F. (1992). Radioimmunoassay of a bovine pregnancy-associated glycoprotein in serum: its application for pregnancy diagnosis. Biology of Reproduction, 46, 83-92. http://dx.doi.org/10.1095/biolreprod46.1.83

\section{Copyrights}

Copyright for this article is retained by the author(s), with first publication rights granted to the journal.

This is an open-access article distributed under the terms and conditions of the Creative Commons Attribution license (http://creativecommons.org/licenses/by/3.0/). 